\title{
Family Centered Bioethics: A New Bioethical Framework for Decision-Making in Neonatal and Pediatric Units
}

\author{
Gonzalez-Melado $\mathrm{FJ}^{1^{*}}$, Teleman $\mathrm{AA}^{2}$ and Di Pletro $\mathrm{ML}^{2}$ \\ ${ }^{1}$ High Centre for Theological Studies, Badajoz, Spain \\ ${ }^{2}$ School of Medicine, Catholic University of Sacred Hearth, Rome, Italy
}

"Corresponding author: Gonzalez-Melado FJ, Casa de la Iglesia San Juan de Ribera, C/Manuel Saavedra Martínez, CP 06011, Badajoz, Spain, Tel: +34630438796; Email: ferminjgm@hotmail.com

Received date: January 20, 2016; Accepted date: March 08, 2016; Published date: March 11, 2016

Copyright: $@ 2016$ Gonzalez-Melado FJ, et al. This is an open-access article distributed under the terms of the Creative Commons Attribution License, which permits unrestricted use, distribution, and reproduction in any medium, provided the original author and source are credited.

\begin{abstract}
Pediatric bioethics emerged from the transfer of the framework of bioethical reflection on adult competent patients, which focuses on the principle of autonomy, to minors and incompetent patients. However, we believe that the framework of patient autonomy is not appropriate for pediatric bioethics and propose a new framework based on the moral responsibility of parents and health care professionals towards the needs of the sick child. The essential elements in creating a new framework for pediatric bioethics are: the primacy of the principle of beneficence, over the principle of autonomy; the therapeutic alliance as an affective and genuine union between the physician, child patient and parents; the therapeutic intentionality as the engine of this alliance; and finally, a real family centered care. These elements establish the bioethical framework of neonatal and pediatric units, by integrating the child's interests within the family's, and permits us to propose an authentically family-centered bioethics.
\end{abstract}

Keywords: Pediatric; Bioethics; Family centered care; Beneficence; Autonomy

\section{A New Framework for Pediatric Bioethics Reflection}

Pediatric bioethics emerged from the transposition of the framework for the reflection on adult competent patients, which focuses on the principle of autonomy, to the reflection on minors and incompetent patients [1]. However, if we analyze pediatric bioethics starting from the principle of autonomy, the only possible standard becomes the child's best interest [2], since its origin has been associated with the evaluation of treatments through the concept of expected quality of life (QL) [3] and has been widely criticized [4] and reformed [5]. This standard leads towards two extreme situations:

A bioethics focused exclusively on the child, where the physicians are the ones who make decisions, by evaluating the expected quality of life (QL) of the child, and therefore deciding if the child has a life worth living [6].

A bioethics focused on the respect of the autonomy of the parents, whose right to take decisions is based on their understanding about what the child's best interest is, and where the physicians simply implement the parents' decisions [7].

We believe that the framework of a patient's autonomy is not appropriate for pediatric bioethics for two reasons: a) In children and young adolescents the level of self-determination that is present in adults is lacking; b) In the care of a sick child, one must not forget that the parents remain responsible for the custody of the child, who is a growing human being with needs. The sick child, in fact, is not so much an autonomous individual but, above all, a member of a family unit. The family should therefore appear at the center of pediatric bioethical reflection.
As a consequence, we should move from a triangular picture representing the relations between the medical team, child and family, which is characteristic of a pediatric bioethics based on autonomy, to a circular image, in which the child is placed in the center (Table 1). Physicians, while considering a child's needs, must take into account not only their responsibilities towards the patient, but also those towards the family [8-9].

\begin{tabular}{|c|c|c|}
\hline $\begin{array}{l}\text { Pediatric } \\
\text { bioethics }\end{array}$ & Image of reference & Elements \\
\hline $\begin{array}{l}\text { Pediatric } \\
\text { bioethics } \\
\text { based on } \\
\text { autonomy }\end{array}$ & Family & $\begin{array}{l}\text { Problems to resolve } \\
\text { - What is the best interests of the } \\
\text { child? } \\
\text { - Who should decide what is the bes } \\
\text { interests of the child? The parents? } \\
\text { The medical team? }\end{array}$ \\
\hline $\begin{array}{l}\text { Family } \\
\text { centered } \\
\text { pediatric } \\
\text { bioethics }\end{array}$ & $\begin{array}{l}\text { Medical team } \\
\text { Family } \\
\text { Child }\end{array}$ & $\begin{array}{l}\text { - A bioethics based on beneficence } \\
\text { - A therapeutic alliance between the } \\
\text { parents and the medical team } \\
\text { - A Family-centered Care perspective }\end{array}$ \\
\hline
\end{tabular}

Table 1: Two bioethical frameworks for decision-making in neonatal and pediatric units.

The new framework for pediatric bioethics is based on the moral responsibility of parents and health care professionals towards the needs of the sick child. This framework is based on three elements:

- Beneficence should be the primary principle. In general, in adult bioethics the standard of respect of a patient's autonomy has priority 
over the norm of beneficence. However, in pediatric bioethics, beneficence takes precedence over autonomy [10].

- The therapeutic alliance is not between the physician and patient but between the physician and the whole family (physician - parents + child). Pediatricians should forge a therapeutic alliance with the patient and the family and the best interest of the child standard should be invoked only when this alliance is broken or cannot be created.

- A Family Centered Cared perspective (FCC) [8]. In the 70's, the question was who should be ultimately responsible for an adult's medical decisions? The answer was clear: the responsibility is of the patient himself. In pediatric medicine, the answer to this same question is also clear: the responsibility for a child's medical decisions is ours [10]. It is our responsibility as a society to promote a child's welfare and development. As opposed to adult bioethics, in pediatric bioethics it is not possible to promote an approach in which the child's rights are analyzed against those of the parents or physicians [11]. We believe that FCC is a more correct approach [12]. On a FCC perspective, the cooperation between physicians and parents is crucial in determining the overall goal of healing and of promoting ethically appropriate treatments.

We place in the center of this framework the moral responsibility of parents and health care professionals, in relation to the needs of the sick child [13]. There is a social responsibility to care for minors that moves between two extremes: the ethics of care, which is based on the specific and particular situation of each patient, and the ethics of justice, based on general principles and standards applied to specific cases with a specific concern for equal opportunities and the distribution of resources. We believe that even though the responsibility of parents and physicians in caring for a child presupposes justice, it extends far beyond justice, arriving closer to the ethics of virtues [14].

\section{Beneficence as the Primary Principle}

The principle of beneficence refers to the moral obligation to act for the benefit of others. The principle of beneficence is interpreted in different ways and with varying degrees of rigor, depending on what is intended as acting for the patient's good. The utilitarianism understood this good as maximizing benefits at the lowest possible cost [15]. Others expand the limits of beneficence to the situations in which one does not sacrifice something of equal moral importance [16]. We embrace a concept of beneficence, rooted in the very nature of medicine, as a special human activity, with its own internal morality, which is set by the physician-patient relationship and is based on the medical act [17]. In medical practice, the principle of beneficence is to act for the patient's good. But what does it really mean to act "for the patient's good"?

One of the goods that doctors and parents of a sick child should seek is the child's health. This could be called the medical good. Usually this good corresponds to a specific medical treatment [18]. To achieve this good, the physician must be competent in his/her profession. Yet this is not sufficient. There are other goods that need to be considered in the physician-patient relationship: the ultimate good of the patient; the patient's own perception of what is his/her good; the good of the patient as a human person. Parents of a sick child want the physician to help them regain the medical good for their child, but it is clear that one can't equate all the good of the person with the medical good [19]. Therefore, it is necessary to establish a hierarchy in these goods: the first would be the ultimate good of the patient followed by the good of the patient as a human person. Next would come the best interest of the patient, i.e., the good that is perceived by the patient, and finally the medical good. In fact, the form of beneficence that we are analyzing is one that considers the patient's welfare in a broader sense than merely their medical well-being [20].

\section{Beneficence in trust}

The physician-patient relationship is characterized by the act in which the patient seeks the physician with the request to help him/her regain health. However, in pediatric medicine, this gesture is carried out by the parents who bring the child to the physician with the request to restore the child's health. The doctor's response to this request becomes an obligation called beneficence in trust [20]. The physician is committed to building a relationship with the family that assures the respect for the parents' autonomy and values and, at the same time, a complete attention towards the patient's medical good (i.e. to the child that needs to be treated). The beneficence in trust becomes the shaping principle of the physician - parents + child relationship. There are several levels in which the trust that qualifies the principle of beneficence becomes clear [20]:

- The first level refers to the asymmetry in the physician - parents + child relationship. This inequality is determined by the vulnerability of the parents, especially those who have a seriously ill child [21]. The physician, in fact, acquires power not only over the sick child, but also over the parents. In such situations, the burden of the obligation lies on the subject who has the power [22].

- The second level of trust refers to the trust that parents must confide in the physicians when taking decisions regarding their child's treatment [20].

- The third level of trust refers to the moral nature of the decisions, which should not be reduced simply to the medical good. In fact, medical decisions include both technical and moral aspects. Physicians should be in sufficient trust to express his/her moral reservations regarding, for example, the parents' refusal to accept certain treatments that the physician considers appropriate, or, vice-versa, the parents' insistence to request a treatment that the doctor believes futile [20]. The norm of the benefit of the patient limits the parents' power and gives the physicians more prerogatives in order to take decisions [10].

- The fourth level of trust should be called the social level, since it derives from the confidence that society places in the individuals who have undergone medical studies [19]. Society must, in fact, continue to maintain this confidence in physicians and therefore political decisions that affect the practice of medicine should not be taken or imposed without the consensus of the medical associations [20].

- The final level of trust might be called the moral implication [20]. The physician, in the therapeutic alliance with the parents of the sick child, is ultimately responsible for the patient. The doctor is the last guardian of the patient's life and health [18]. This is the moral responsibility that allows the physician to act against the will of the parents, if they are putting at risk the best interest of the child [22].

\section{Mediated beneficence}

We have already seen some of the characteristics of the beneficence in trust principle. When applied to pediatric medicine, we realize that we must talk about a mediated beneficence: "Given that parents or guardians are presumed to be the child's primary caretaker, a health 
care provider's duty to care for children is mediated by parental obligations" [10]. In pediatric medicine, the relationship of health workers with the family can be difficult. A strict application of the principle of beneficence could put the physicians in a position of superiority in respect to the parents, who are primarily responsible for the children. This is where we detect one of the sources of conflict: parents -not physicians- are primarily responsible for the child. In pediatric medicine, the relationship is different from that found in adult medicine, and therefore the moral situation is also more complex. In fact, the work of the physicians must take into consideration the child, the child's family and the physician's own moral and professional responsibility. When making decisions in pediatrics, the parents' opinion cannot be ignored in absence of sufficient motivation. Furthermore, there are the reasons for which it is necessary to respect parental authority and the family's privacy [10]:

a. Reason of Intimacy: The family, seen as a space characterized by intimate relationships, offers to each of its members a context in which they can find a meaning in their life, experience feelings and transmit values from generation to generation. Family intimacy requires a good measure of privacy. Physicians, and other social agents, should generally be reluctant to determine a family's decision, unless it is necessary to avoid something that is clearly harmful for the child [23].

b. Epistemological reason: The family usually knows the child better than the health professionals, and is therefore in a better position to decide in favor of the child. This knowledge is not based only on the physical history but also on the values and priorities with which the child has grown up [10].

The family plays a central role in the formation of the individual identity [24]. Culture, education, values and religion that we have received in our family help us to develop our capacities and allow us to make the choices that will configure our way of life.

The last reason leads us to issues of freedom and responsibility [25]. The family is the one that has to bear the economic and psychological costs of medical decisions for the child, and should, therefore, have control over the decisions regarding treatment.

These reasons lead us to respect parental autonomy and family privacy when parents must take medical decisions regarding their child. But respect for the parents' autonomy in pediatric medicine is not the same as respect for a patient's autonomy in adult medicine [26]. Parental autonomy is instrumental and is conditioned and limited by the child's welfare. Parents cannot take decisions regarding their child's medical treatment that are irresponsible from a medical point of view [10]. The physicians' professional responsibility in pediatrics should be guided by the rule of mediated beneficence, requiring physicians to be able to coordinate their commitments for the welfare of the patient, with the opportunities and limits that are given by the needs of the patient, and the context and preferences of the child's family.

\section{The Therapeutic Alliance}

In pediatrics, the health professional must establish a therapeutic alliance with the patient's parents or guardians. This alliance includes, among its responsibilities, the necessity to protect the present and future interests of the child and its family [9]. The therapeutic alliance, established between the physician and the parents of the sick child, is marked by an asymmetrical relationship. Indeed, the relationship is based on the vulnerability of the sick person [14] (the child) and the physician's disposition to help the child and its parents [21], making it possible for the child to regain health. Healing appears as the intentional element of the relationship, therefore making it a therapeutic alliance.

This model, which considers the physician - parents + child relationship as an alliance, is centered on disease and the inequality that exists between the parent + child and the physician. Physicians have the knowledge and capacity to obtain healing. Therefore, we can say that the beneficence in trust, as a principle, and the virtue that enables it, benevolence, are grounded in the humanity of people who interact in the medical relationship [27], that in this case is the physician - parents + child relationship [28].

This covenant, which is between parents and physicians, has the goal of achieving the best interests of the child. The best interests of the child should be, in principle, to obtain the good health of the child. Analyzing the medical procedures, we recognize the presence of two elements that are always present in all intentional human actions [29]: 1) the goal is already at the origin of all medical pediatric actions; 2 ) the therapeutic intentionality configures the alliance between doctors and parents.

The intention of doing something is completely different from the desire of doing something. In fact, a simple desire does not necessarily lead to an action. It is the intentionality that is the engine and soul of an action. In our case, the intention is to choose what are the best interests for the child's health. It is therefore a therapeutic intention. When we choose a particular treatment and when we put it into practice we are already anticipating the end, which is, in fact, to achieve the best interests of the child.

The therapeutic intentionality is therefore the basis on which the therapeutic alliance between physician and parents rests [29]. If parents were to take decisions against the child's medical interests, the physicians may break this alliance and adopt an attitude of pediatric paternalism [10], i.e., to make decisions to protect the medical interests of the child, ignoring the parental autonomy [30]. However, medical pediatric paternalism must be the exception rather than the rule, and medical care in pediatrics should ideally be centered on the entire family.

\section{A Family Centered Care}

In the last decade, a health paradigm, called patient-centered care that draws attention to the personal experiences of people who have illness or disabilities, has begun to gain importance [31]. This paradigm has been developed in pediatric medicine, where the term family-centered care (FCC) is normally being used to describe this way of delivering health services [9]. FCC is an approach built on the cooperation between the family and medical team in making decisions regarding the patient. The FCC approach has been adopted by many physicians, hospitals and health-care groups as the standard of care, thus becoming the "cornerstone" [32] of pediatric medicine.

FCC is an optimal form of health care from the family's point of view [29]. FCC aims to engage and empower families in the care of children, going far beyond the simple doctor-patient relationship, and considering the needs of the whole family and not merely the needs of the child [32,33]. However, even though there still isn't an unanimously accepted definition of FCC, The Institute for Patient-and Family-Centered Care highlights on its website that:

"Patient-and family-centered care is an approach to the planning, delivery, and evaluation of health care that is grounded in mutually 
beneficial partnerships among health care providers, patients, and families. It redefines the relationships in health care [34]."

This definition is strongly influenced by the expansion of the application of the FCC approach to patients of all ages [32]. There are some principles of the FCC [35-37] that should be present in a Family Centered Bioethics: a) The medical team has to share all information with the family; b) It is necessary to respect and recognize the differences of each family; c) A total cooperation and collaboration between the medical team and the family is necessary; d) Negotiation is a disposition that has to be present in the medical team and in the family in order to take appropriate decisions; e) The medical team has to prescribe the care and support in the context of the family and family's community (Table 2). The American Academy of Pediatrics defines FCC as a model of health care based on the understanding that the family is the main source of strength and support for the child. It also recognizes that correctly informing and taking in consideration the opinions of both child and family are important elements in the clinical decision process [9]. FCC also aims at empowering parents so that they can participate more in the care for their child, enhancing the capabilities of the child and therefore better meeting the child's needs [38].

From this definition, three elements emerge: a) that parents know what is best for their children and desire the best for their children; $b$ ) all families are unique and different from each other, and c) that the best care for a sick child is only possible within a context of support from both the family and the community in which the family is a part of.

\begin{tabular}{|l|l|}
\hline Principles & Content \\
\hline $\begin{array}{l}\text { Share all } \\
\text { information }\end{array}$ & $\begin{array}{l}\text { An open and objective communication between the medical } \\
\text { team and family, especially with parents, sharing information } \\
\text { in a complete and impartial way. }\end{array}$ \\
\hline $\begin{array}{l}\text { Respect and } \\
\text { recognize the } \\
\text { differences }\end{array}$ & $\begin{array}{l}\text { Respecting the needs and preferences of each child and } \\
\text { family. Recognizing and honoring racial, ethnic, cultural, } \\
\text { socioeconomic and Spiritual differences, which have an } \\
\text { influence on family experiences and perceptions of attention } \\
\text { and care. }\end{array}$ \\
\hline $\begin{array}{l}\text { Cooperation and } \\
\text { collaboration }\end{array}$ & $\begin{array}{l}\text { Family and doctors work together for the best interests of } \\
\text { the child and family, participating in decision-making about } \\
\text { treatment, attention and care of the child. }\end{array}$ \\
\hline $\begin{array}{l}\text { Negotiation } \\
\text { Decisions are taken together because there is a disposition } \\
\text { in all to negotiate, and to discover family strengths so they } \\
\text { can make appropriate decisions. }\end{array}$ \\
\hline $\begin{array}{l}\text { Care and support } \\
\text { in the context of } \\
\text { family and } \\
\text { family's } \\
\text { community }\end{array}$ & $\begin{array}{l}\text { We need to develop health policies that will be family- } \\
\text { centered and that will respond to the needs of the } \\
\text { populations where the family live, with assistance and home } \\
\text { care programs, especially for chronic diseases, promoting } \\
\text { the child's attention and care at home. }\end{array}$ \\
\hline
\end{tabular}

Table 2: FCC principles that serve us for a Family Centered Bioethics.

It is clear that FCC is an approach that moves away from the previous model focused on the physician as a dispenser of services [39]. The FCC model involves family participation in decision-making process, mutual respect between the medical team and the family, respect for decisions taken, individualized and flexible care, sharing all information and training parents to care better for their children [40]. This framework for neonatal and pediatric care helps us develop our new framework for pediatric bioethics. The Family Centered Bioethics is based on the theory of the family as a system, and recognizes the need to ensure the welfare of the family in order to achieve the child's welfare [41].

\section{Conclusion}

The framework of a patient's autonomy is not appropriate for neonatal and pediatric units. We propose a family-centered bioethics as a new bioethical framework for neonatal and pediatric units. The essential elements to establish this new framework for pediatric bioethics are:

The primacy of the principle of beneficence, over the principle of autonomy. This primacy enables us to consider the physician-parentschild relationship not as a struggle of rights and duties, but as a real relationship based on the common search for the child's health. This final objective is made possible through the confidence that parents put in the medical team.

This mediated beneficence provides a true therapeutic alliance between the physicians with the sick child, through the parents. This therapeutic alliance allows a genuine and affective union between the physician, child patient and parents through the physician's compassion. The best interest of the child becomes for the physician a proper end to share with the parents as a common act. Every action in pediatric medicine has its origins in the search for the best interests of the child.

Therapeutic intentionality is the engine of this alliance and, at the same time, it establishes its limits. Parental decisions that go against the child's medical interests, in fact, break this alliance. Therefore, pediatric medicine cannot consider a sick child as an isolated element, but must consider the child within its family as a whole.

FCC opens the framework of pediatric bioethics by integrating within the child's interests the interests of the family as well, therefore allowing us to propose a true Family Centered Bioethics as a new bioethical framework for decision-making in neonatal and pediatric units.

\section{Competing Interests}

Authors declare that they do not have competing interests regarding this research.

\section{References}

1. Buchanan AE, Brock DW (1989) Deciding for others: The ethics of surrogate decision making. Cambridge University Press.

2. Kopelman LM (2007) The best interests standard for incompetent or incapacitated persons of all ages. J Law Med Ethics 35: 187-196.

3. Placencia FX, McCullough LB (2011) The history of ethical decision making in neonatal intensive care. J Intensive Care Med 26: 368-384.

4. González-Melado FJ, Di Pietro ML (2015) [The Best Interest of the Child in Neonatology: Is It Best for the Child?]. Cuad Bioet 26: 201-222.

5. González-Melado FJ (2015) Dominic Wilkinson: Death or disability? The "Carmentis Machine" and decision-making for critically ill children. Theor Med Bioeth 36: 363-368.

6. Kushe H, Singer P (1985) Should the Baby Live? The problem of Handicapped Infants. Oxford University Press, Oxford, USA.

7. Goldstein J, Freud A, Solnit AJ (1979) Before the best interests of the child. The Free Press, New York.

8. Committee On Hospital Care And Institute For Patient- And FamilyCentered Care (2012) Patient-and family-centered care and the pediatrician's role. Pediatrics 129: 394-404. 
Citation: Gonzalez-Melado FJ, Teleman AA, Luisa Di Pietro M (2016) Family Centered Bioethics: A New Bioethical Framework for DecisionMaking in Neonatal and Pediatric Units. J Clin Res Bioeth 7: 263. doi:10.4172/2155-9627.1000263

Page 5 of 5

9. Committee on Hospital Care American Academy of Pediatrics. (2003) Family-centered care and the pediatrician's role. Pediatrics 112: 691-697.

10. Miller RB (2003) Children, ethics and modern medicine. Indiana University Press, Bloomington.

11. Erickson SA (2010) The wrong of rights: the moral authority of the family. J Med Philos 35: 600-616.

12. Kuo DZ, Houtrow AJ, Arango P, Kuhlthau KA, Simmons JM, et al. (2012) Family-centered care: current applications and future directions in pediatric health care. Matern Child Health J 16: 297-305.

13. Di Pietro ML, Refolo P, González-Melado FJ (2012) [About $<$ responsibility $>$ of vaccination]. Cuad Bioet 23: 323-336.

14. Pérez-Soba J (2009) Il bene della vita e della salute e il dovere di preservarli, In: Sgreccia E, Laffitte J. (eds.) Accanto al malato inguaribile e al morente: orientamenti etici ed operativi. Atti della quattordicesima assemblea generale della Pontifica Accademia per la Vita. Libreria Editrice Vaticana: 91-115.

15. Beauchamp TL, Childress JF (2009) Principles of biomedical ethics. Oxford University Press, New York.

16. Singer P (1972) Famine, affluence and morality. Philososphy and Public Affairs 1: 229-243

17. Pérez-Soba JJ (2015) Acto médico, in C. Simón, (ed.), Nuevo diccionario de bioética. Monte Carmelo, Burgos.

18. Pellegrino ED, Thomasma DC (1988) For the patient's good: The restoration of beneficence in health care. Oxford University Press, New York.

19. Arduini C (2009) La razionalità dell'agire del medico e il ruolo delle virtù, Edizioni Messagero. Padova 286, pp. 24.

20. Pellegrino ED, Thomasma DC (1993) The virtues in the medical practice. Oxford University Press, New York.

21. Hauerwas S (2004) Naming the silences. God, medicine and the problem of suffering. William B. Eerdmans Publishing Company, Grand Rapids.

22. Pellegrino ED, Harvey JC (2001) Whom should the patient trust? A friendly report to Kevin Wildes. America (NY) 185: 19, 22-23.

23. Schoeman F (1980) Rights of children, rights of parents, and the mora basis of the family. Ethics 91: 6-19.

24. López F (1984) La adquisición del rol y la identidad sexual: función de la familia. Journal for the Study of Education and Development 26: 65-75.

25. Di Pietro ML (2008) Bioetica e famiglia. Lateran University Press, Rome.

26. Page E (1984) Parental rights. Journal of Applied Philosophy 1: 187-203.
27. MacIntyre A (1999) Dependent rational animals: Why human beings need the virtues. Open Court Publishing.

28. McCullough LB (2009) Contributions of ethical theory to pediatric ethics: Pediatricians and parents as co-fiduciaries of pediatric patients. Cambridge University Press, New York 2009, 11-21.

29. Rhonheimer M (2011) The Perspective of Morality: Philosophical Foundations of Thomistic Virtue Ethics. Catholic University of America Press, Washington DC.

30. Macklin R (1982) Return to the best interests of the child, in Gayling W, Mackling R., (eds.) Who speaks for the child. The problems of proxy consent. Plenium Press, New York, pp:265-302.

31. Crossing the quality chasm: A new health system for the 21 st century. The National Academies Press, Washington DC. (2001) Institute of Medicine.

32. Shields L, Pratt J, Hunter J (2006) Family centred care: a review of qualitative studies. J Clin Nurs 15: 1317-1323.

33. Arango P (1999) A parent's perspective on family-centered care. J Dev Behav Pediatr 20: 123-124.

34. Institute for Patient -and Family-Centered Care. Frequenly asked questions.

35. Moore KA, Coker K, DuBuisson AB, Swett B, Edwards WH (2003) Implementing potentially better practices for improving family-centered care in neonatal intensive care units: successes and challenges. Pediatrics 111: e450-460

36. Law M, Teplicky R, King S, King G, Kertoy M, et al. (2005) Familycentred service: moving ideas into practice. Child Care Health Dev 31: 633-642.

37. Lotze GM, Bellin MH, Oswald DP (2010) Family-Centered Care for children with special health care needs: Are we moving forward? J Family Social Work 13: 100-113

38. King S, Teplicky R, King G, Rosenbaum P (2004) Family-centered service for children with cerebral palsy and their families: a review of the literature. Semin Pediatr Neurol 11: 78-86.

39. Cooley WC, McAllister JW (1999) Putting family-centered care into practice--a response to the adaptive practice model. J Dev Behav Pediatr 20: $120-122$.

40. Shelton TL (1999) Family-centered care in pediatric practice: when and how? J Dev Behav Pediatr 20: 117-119.

41. Bamm EL, Rosenbaum P (2008) Family-centered theory: origins, development, barriers, and supports to implementation in rehabilitation medicine. Arch Phys Med Rehabil 89: 1618-1624. 